Nikita Saiyam et al, International Journal of Advances in Agricultural Science and Technology,

Vol.8 Issue.2, February-2021, pg. 49-54

ISSN: 2348-1358

Impact Factor: 6.057

NAAS Rating: 3.77

\title{
A Study on Job Performance of Anganwadi Workers under ICDS Scheme in Sehore District of Madhya Pradesh
}

\author{
Ms. Nikita Saiyam*; Dr. Deepak Kumar Verma**; Dr. Sandhya Choudhary*** \\ *M.Sc. Student 2020, College of Agriculture, Indore \\ **Assistant Professor (Contractual), Department of Extension \& Communication College of Agriculture, Indore \\ ***Professor \& Head, Department of Extension \& Communication, College of Agriculture, Indore \\ DOI: 10.47856/ijaast.2021.v08i2.007
}

\begin{abstract}
Under ICDS various jobs are assigned to Anganwadi workers which include coordination with block and district health care establishments to avail medical schemes and to help pregnant/lactating women and infants for nutrition supplements. Anganwadi workers also focus to ascertain immunization and health check-ups for women and children. They organize supplementary nutrition for feeding infants and keep a record of expecting mother's childbirths and diseases/infections of any kind. They work proactively to spread awareness of health schemes run by government and inform supervisors for village's health progression, or issues needing attention and intervention. Keeping in view the job performance of Anganwadi workers was studied by taking 120 Anganwadi workers of Sehore district. The main finding is that most of the Anganwadi workers $(40.00 \%)$ had moderate job performance, $34.17 \%$ of workers had low job performance whereas, only 25.33\% Anganwadi workers had high job performance.
\end{abstract}

\section{Introduction}

Integrated Child Development Service (ICDS) is India's response to the challenge of meeting the holistic needs of the child, launched Initially in 33 blocks (5th Five year plan), on October 2, 1975. It aims at enhancing survival and development of children from the vulnerable sections of the society. An Anganwadi is the focal point for the delivery of ICDS services to children and mothers. In Madhya Pradesh there are total 97135 Anganwadi Kendra (by Ministry of Women and Child Development, 26th July 2019). The program is executed through dedicated cadre of female workers: the Anganwadi workers, the Anganwadi helpers, Supervisors and District Child Development Protection Officers (CDPOs). The Anganwadi worker is the most important functionary of the ICDS scheme. The Anganwadi worker is a community based front line worker of the ICDS program.

So, under ICDS it becomes very important to observe the behavior of people which is relevant to the goals of the organization. Hence Job performance has been defined as the overall expected value from employees' behaviors carried out over the course of a set period of time (Motowidlo, Borman, \& Schmidt, 1997)

\section{Objective}

To assess the job performance of Anganwadi workers. 


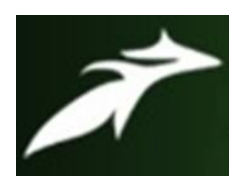

Nikita Saiyam et al, International Journal of Advances in Agricultural Science and Technology, Vol.8 Issue.2, February-2021, pg. 49-54

ISSN: 2348-1358

Impact Factor: 6.057

NAAS Rating: 3.77

\section{Review of Literature}

Parliwal et al. (2011) studied care work by examining two categories of non-family care workers; hired domestic workers and Anganwadi workers, classified as volunteer workers in a government program. The Anganwadi workers enjoy some special standings and relatively extensive unionization compared with domestic workers. Also, domestic workers have much harder trade-offs between their Family's livelihood and daily care needs. however economic undervaluation is common in both the categories.

Desai et al. (2012)revealed that the integrated child and development scheme was initiated nearly 35 years ago in response to the evident problems of persistent hunger \& malnutrition specially among the committee. To understand these changing roles, the present study was initiated with the objective to study the changing role of Anganwadi workers in the present scenario and the problems of the mere amount given to them as wages.

Parliwal et al. (2012) threw light on Women's exclusion from male dominated society, public areas and gendered divisional society. On the other hand, opportunities for employment have grown for educated women but with a very slow economic growth. The AWW is an example of it, where the women's participation has increased in the past 10 years but is marked with a very slow rate of increase in the facilities, incentives and salaries provided to them.

Sangeetha (2019) showed that majority (64\%) of the samples were just satisfied in implementing the ICDS activities, $34 \%$ were moderately satisfied, and $2 \%$ were fully satisfied whereas none of them were unsatisfied or fairly satisfied.

\section{Method \& Material}

The sample of the present study was selected by proportionate random sampling method. A list of Anganwadi workers from 30 Anganwadi villages was taken from Ichhawar block in Sehore district. Each Anganwadi Centre has 4 workers and they attend the training program at block level. In this manner 120 Anganwadi workers was treated as respondents for the present study.

This was an exploratory survey method. In this study, the sample size was 120 Anganwadi workers implementing Integrated Child Development Scheme activities in Sehore. The Anganwadi workers were briefed about the purpose, procedure, confidentiality, risks, and benefits of the study. The setting for the study was at the child development project office.

An interview schedule method was planned for collecting the relevant collection of selected variables. The data were collected personally with the help of pre tested interview schedule. The researcher personally contacted the respondents. They were assured that the information given by them would be kept confidential and it would only be used for the academic purposes. 


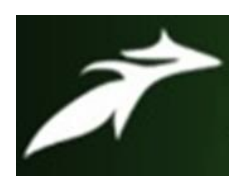

Nikita Saiyam et al, International Journal of Advances in Agricultural Science and Technology, Vol.8 Issue.2, February-2021, pg. 49-54

ISSN: 2348-1358

Impact Factor: 6.057

NAAS Rating: 3.77

\section{Result \& Discussion}

Assessment of the Job Performance of Anganwadi workers:

Table: Job performance of Anganwadi workers:

$n=120$

\begin{tabular}{|c|c|c|c|c|c|}
\hline \multirow[t]{2}{*}{ S.NO. } & \multirow[t]{2}{*}{ Statement } & \multicolumn{3}{|c|}{ Level of job performance } & \multirow{2}{*}{$\begin{array}{l}\text { Mean } \\
\text { score }\end{array}$} \\
\hline & & Low & Medium & High & \\
\hline 1. & \multicolumn{5}{|l|}{ Vaccination related } \\
\hline a. & $\begin{array}{l}\text { To protect children from tuberculosis, the Anganwadi } \\
\text { worker has full responsibility to vaccinate BCG at birth } \\
\text { or one month after birth. }\end{array}$ & 19 & 46 & 55 & 2.30 \\
\hline b. & $\begin{array}{l}\text { To protect children from polio disease, you work to } \\
\text { give the first dose in the first month itself. }\end{array}$ & 21 & 49 & 50 & 2.24 \\
\hline c. & $\begin{array}{l}\text { Children should be given at least five doses of vitamin- } \\
\text { A till the age of } 3 \text { years. }\end{array}$ & 23 & 53 & 44 & 2.17 \\
\hline d. & $\begin{array}{l}\text { Vaccine should be applied in } 9^{\text {th }} \text { month to avoid } \\
\text { measles. }\end{array}$ & 16 & 49 & 55 & 2.32 \\
\hline 2. & \multicolumn{5}{|c|}{ Nutrition and health education related } \\
\hline a. & $\begin{array}{l}\text { Due to lack of adequate nutrition the highest risk of } \\
\text { malnutrition is in children between } 6 \text { months to } 2 \text { years, } \\
\text { you make people aware of these things. }\end{array}$ & 44 & 51 & 25 & 1.84 \\
\hline b. & $\begin{array}{l}\text { To protect children from polio disease, you work to give } \\
\text { the first dose in the first month itself. }\end{array}$ & 39 & 45 & 36 & 1.97 \\
\hline c. & $\begin{array}{l}\text { Children should be given at least } 5 \text { doses of Vit A till the } \\
\text { age of } 3 \text { years, for this you work with full dedication. }\end{array}$ & 46 & 49 & 25 & 1.82 \\
\hline d. & $\begin{array}{l}\text { For the prevention of diseases due to deficiency of other } \\
\text { vitamin and proteins, you provide fruit \& vegetable on } \\
\text { proper basis. }\end{array}$ & 45 & 36 & 39 & 1.95 \\
\hline e. & $\begin{array}{l}\text { You participate in each and every training program to } \\
\text { provide nutrition and health education. }\end{array}$ & 49 & 52 & 19 & 1.75 \\
\hline 3. & \multicolumn{5}{|l|}{ Informal education } \\
\hline a. & $\begin{array}{l}\text { You work to give informal education to children from } 3 \\
\text { to } 6 \text { years }\end{array}$ & 56 & 41 & 23 & 1.72 \\
\hline b. & $\begin{array}{l}\text { You provide the means for different sports and children's } \\
\text { stories }\end{array}$ & 49 & 55 & 16 & 1.72 \\
\hline
\end{tabular}




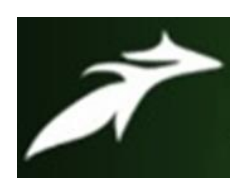

Nikita Saiyam et al, International Journal of Advances in Agricultural Science and Technology, Vol.8 Issue.2, February-2021, pg. 49-54

ISSN: 2348-1358

Impact Factor: 6.057

NAAS Rating: 3.77

\begin{tabular}{|c|c|c|c|c|c|}
\hline c. & $\begin{array}{l}\text { For the physical, mental and intellectual development of } \\
\text { children, you undertake } 4 \text { to } 5 \text { hours of interesting } \\
\text { activities daily. }\end{array}$ & 48 & 54 & 18 & 1.75 \\
\hline d. & $\begin{array}{l}\text { You participate enthusiastically in every training for } \\
\text { informal education. }\end{array}$ & 38 & 49 & 33 & 1.95 \\
\hline 4. & \multicolumn{5}{|l|}{ Health Check up } \\
\hline a. & $\begin{array}{l}\text { You are employed for serial inspection of pregnant } \\
\text { women like blood pressure, blood test, stomach test. }\end{array}$ & 24 & 47 & 49 & 2.20 \\
\hline b. & $\begin{array}{l}\text { You ensure that pregnant women should gain } 10 \mathrm{~kg} \\
\text { weight in } 9 \text { months. }\end{array}$ & 31 & 38 & 51 & 2.17 \\
\hline c. & $\begin{array}{l}\text { Till the age of } 3 \text { years, you provide nutrition to } \\
\text { malnourished child. }\end{array}$ & 33 & 46 & 41 & 2.06 \\
\hline d. & $\begin{array}{l}\text { You work to weigh the child up to the age of } 3-5 \text { years at } \\
\text { an interval of every } 2 \text { months. }\end{array}$ & 46 & 52 & 22 & 1.80 \\
\hline e. & $\begin{array}{l}\text { You participate in every training program to get } \\
\text { information about health check-up. }\end{array}$ & 43 & 49 & 28 & 1.87 \\
\hline 5. & \multicolumn{5}{|l|}{ Reference service } \\
\hline a. & $\begin{array}{l}\text { Beneficiaries need a special card to take advantage of } \\
\text { various scheme, you get them made. }\end{array}$ & 31 & 44 & 42 & 2.04 \\
\hline b. & $\begin{array}{l}\text { Strive to provide financial help to the beneficiaries in } \\
\text { medical examination. }\end{array}$ & 38 & 42 & 40 & 2.01 \\
\hline c. & $\begin{array}{l}\text { You attend every training program to get information } \\
\text { about health check-up. }\end{array}$ & 47 & 45 & 28 & 1.84 \\
\hline 6. & \multicolumn{5}{|c|}{ Supplementary nutrition related diet } \\
\hline a. & $\begin{array}{l}\text { To provide } 12-15 \text { grams of protein to children from } 6 \\
\text { months to } 6 \text { years, you plan / distribute supplements, } \\
\text { For example; aata, besanladdu, upma, khichdi, halwa, } \\
\text { namkeen and daliya etc. }\end{array}$ & 42 & 49 & 29 & 1.89 \\
\hline b. & $\begin{array}{l}\text { You encourage pregnant mothers and teenagers to take } \\
18-20 \text { grams of protein. }\end{array}$ & 39 & 43 & 38 & 1.99 \\
\hline c. & $\begin{array}{l}\text { Distribute morning breakfast to children from } 3 \text { to } 6 \\
\text { years. }\end{array}$ & 45 & 48 & 27 & 1.85 \\
\hline d. & $\begin{array}{l}\text { You make sure that sweet milk is given to children from } \\
3 \text { to } 6 \text { years. }\end{array}$ & 43 & 53 & 24 & 1.84 \\
\hline e. & $\begin{array}{l}\text { You take part in every training program to get a detailed } \\
\text { information about the diet. }\end{array}$ & 38 & 52 & 30 & 1.93 \\
\hline
\end{tabular}




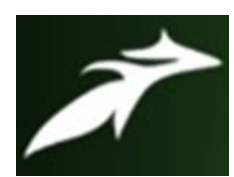

Nikita Saiyam et al, International Journal of Advances in Agricultural Science and Technology, Vol.8 Issue.2, February-2021, pg. 49-54

ISSN: 2348-1358

Impact Factor: 6.057

NAAS Rating: 3.77

\begin{tabular}{|c|c|c|c|c|c|}
\hline f. & $\begin{array}{l}\text { To motivate the women of Anganwadi to get nutritious } \\
\text { food, you inspire them to set up a kitchen garden as } \\
\text { well. }\end{array}$ & 42 & 47 & 31 & 1.90 \\
\hline & $\begin{array}{l}\text { overall consideration with respect in the job } \\
\text { performance }\end{array}$ & $\begin{array}{l}\quad 41 \\
(34.17 \\
\%)\end{array}$ & $\begin{array}{l}48 \\
(40.00 \\
\%)\end{array}$ & $\begin{array}{c}31 \\
(25.33 \%)\end{array}$ & \\
\hline
\end{tabular}

\section{Assess the job performance of Anganwadi workers:}

\section{Vaccination related:}

The data revealed job performance of Anganwadi workers related to vaccination in following sequence; vaccination in $9^{\text {th }}$ month to avoid measles, protection of children from tuberculosis, vaccinate $B G C$ at birth or one month after birth, protect children from polio disease, give the first dose in the first month itself and give five doses of vitamin-A to children till the age of 3 years. This finding is in conformity with the findings as reported by Das et al. (2013) and Akshatha and Surekha (2018).

\section{Nutrition and health education related:}

The data revealed job performance of Anganwadi workers related to nutrition and health education in following sequence; iodine is provided in proper quantity to prevent goitre disease in pregnant women, prevention of disease due to deficiency of other vitamins and proteins, provision of fresh fruits \& vegetable on proper basis, making people aware of the risk of malnutrition in children between 6 month to 2 years due to lack of adequate nutrition, vitamin-A supplements to children from 9 months to 5 years followed by participation in every training program. This finding is in conformity with the findings as reported by Niyi et al. (2011) and Jostein et al. (2012).

\section{Informal education:}

The data revealed job performance of Anganwadi workers related to informal education in following sequence; participation of Anganwadi worker in every training program enthusiastically for informal education, interesting daily activities of 4-5 hours for physical, mental and intellectual development of children, provide means for different sports and children's stories, give informal education to children from 3 to 6 years. This finding is in conformity with the findings as reported by Dasgupta (2013).

\section{Health checkup:}

The data revealed job performance of Anganwadi workers related to health checkup in following sequence; routine inspection of pregnant women such as blood pressure, blood test, stomach test, make sure that pregnant women gain $10 \mathrm{~kg}$ in 9 months, provide nutrition to malnourished child every month till the age of 3 years, participation in every training program to get 


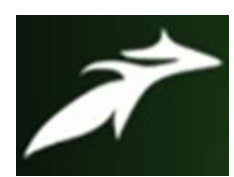

Nikita Saiyam et al, International Journal of Advances in Agricultural Science and Technology, Vol.8 Issue.2, February-2021, pg. 49-54

ISSN: 2348-1358

Impact Factor: 6.057

NAAS Rating: 3.77

information about health checkup, record child's weight of 3 to 5 years of age every 2 months. This finding is in conformity with the findings as reported by Patnaik et al. (2011)

\section{Reference service:}

The data revealed job performance of Anganwadi workers related to referral services in following sequence; provision of special cards to the beneficiaries so that they can take advantage of various schemes, provide financial help to the beneficiaries in medical examination, attend every training program to get information about health checkup. This finding is in conformity with the findings as reported by Mehta et al. (2012).

\section{Supplementary nutrition related diet:}

The data revealed job performance of Anganwadi workers related to supplementary nutrition in following sequence; encourage pregnant mothers and teenagers to take 18 to 20 grams protein, participation in every training program to provide complete external information and to motivate the women of Anganwadi, inspire women to set up a kitchen garden, provide supplementary diet of 12 to 15 gram protein to children from 6 months to 6 years For example; aata, besanladdu, upma, khichdi, halwa, namkeendaliya etc. Distribute morning breakfast and sweet milk to children from 3 to 6 years. This finding is in conformity with the findings as reported by Annie et al. (2011).

\section{References}

[1]. Desai G, Pandit.N, Sharma. D: Changing role of Anganwadi workers; journal of Indian Healthline, vol-1.

[2]. Parliwal K. andNeetha N.2012 between state, market and family- the Indian healthworker; Journal of Indian healthline.

[3]. ParliwalK. And NeethaN.2012 Care arrangements and Bargain; International labour review.

[4]. Parmar,S.K. 2008. A study on repayment behaviour of beneficiaries of Kisan Credit Card scheme in

[5]. Sangeetha F. 2019 Satisfaction of Anganwadi Workers in implementing Integrated Child Development Scheme activities. International Journal of Research and Analytical Reviews6(2): 745-750 